УДК-323

DOI: 10.17072/2218-1067-2021-1-66-73

\title{
ON THE (IN)JUSTICE OF GLOBAL SOCIOECONOMIC INEQUALITIES
}

\section{Fabio Coacci}

Fabio Coacci, postgraduate student, lecturer at the Department of World Political Processes, MGIMO University, Russia, Moscow.

Teaching Assistant at the Department of Political Science, Communication and International Relations, University of Macerata, Italy.

E-mail: f.coacci1@unimc.it. (ORCID: 0000-0002-4504-6067).

\begin{abstract}
Global socioeconomic inequalities are one of the greatest challenges of the contemporary era since they represent a gruesome fact for the whole of humanity. This article seeks to provide a picture of the current socioeconomic inequalities at the global level and analyze the extent to which they ought to be assessed as unjust. To pursue this aim, the article examines the empirical evidence related to the growth in global socioeconomic inequalities and critically assesses them in light of the principle of redress of morally arbitrary inequalities. The article claims that global socioeconomic inequalities are affected by two relevant problematics in both methodological and normative terms. The empirical analysis demonstrates that there is a widespread methodological nationalism that jeopardizes the discussion on socioeconomic inequalities at the global level while the critical assessment of the socioeconomic inequalities shows that their strong injustice can be defended even against the Rawlsian objections to the principle of redress of morally arbitrary inequalities.
\end{abstract}

Keywords: socioeconomic inequalities; globalization; arbitrariness; injustice; methodological nationalism.

The main question this article wants to address is: What is the contemporary level of global socioeconomic inequalities and to what extent they ought to be assessed as unjust? To provide an apt answer to this question both empirical research on the actual socioeconomic inequalities and theoretical studies - at the levels of normative theory and public ethics - on the concept of socioeconomic injustice are taken into account. Hence, the article follows two directions: on the one hand, the actual trend of global socioeconomic inequalities is examined with a particular focus on wealth inequalities; on the other hand, the assessment of the unjustness of the global socioeconomic inequalities is carried out. Therefore, the first part seeks to analyse how things currently are while the second part aims at analysing how things ought to be.

Accordingly, the first part of the article aims to show the size of the global socioeconomic inequalities underlining the spread bias of the empirical research and social scientists to focus on national, let alone regional, socioeconomic inequalities at the expense of global analysis. Meanwhile, the second part delves into the controversial concepts of universal socioeconomic (in)justices which provide the fundamental insights to normatively assess socioeconomic inequalities vis-à-vis the concept of the lottery of birth and the principle of redress of morally arbitrary inequalities.

It goes without saying that both parts are deeply interconnected since the empirical examination of socioeconomic inequalities is supposed to be on the table of discussants of global socioeconomic justice, even for those theorists which want to disprove global socioeconomic inequalities to be a matter of justice (Nagel, 2005: 117). Indeed, the discussion of the fair global distribution of socioeconomic benefits and burdens addresses the assessment of those socioeconomic inequalities which can be defined as unjust. This article argues for the definition of unjust socioeconomic inequalities as morally arbitrary inequalities resulting from the lottery of birth, which, accordingly, call for redress.

\section{A sketch on socioeconomic inequalities}

"Inequality is a violation of human dignity» Göran Therborn

In an attempt to provide a broad explanation of the concept of inequality, Therborn defines it as «a 
denial of the possibility for everybody's human capabilities to develop. It takes many forms, and it has many effects: premature death, ill-health, humiliation, subjection, discrimination, exclusion from knowledge or from mainstream social life, poverty, powerlessness, stress, insecurity, anxiety, lack of self-confidence and of pride in oneself, and exclusion from opportunities and life-chances» (Therborn, 2013: 1). Therefore, the long-debated concept of inequality is subjected to different interpretations and the socioeconomic inequalities, which are going to take into account in this article, are just a dimension of it.

The problem of socioeconomic inequalities has recently attracted considerable interest among philosophers above all thanks to the effort of John Rawls (1971, 1985, 1993; Giovanola, 2016). Until nowadays, outside political philosophy, the topic of socioeconomic inequalities has shown to be not so appealing, even though recently it seems to have been able to catch the attention of authors from different orientations and disciplinary fields (Lenger, Schumacher, 2015), such as the economists Anthony Atkinson (2015), Branko Milanovic (2016), Joseph Stiglitz (2012), Thomas Piketty (2013), Amartya Sen (1980, 1992, 2009), the sociologists Zygmunt Bauman (2011), Luciano Gallino (2009), the jurists Ferrajoli (2001, 2013) and Ronald Dworkin (1977, 1981, 2002), the political scientists David Held (2007) and Nadia Urbinati (2017).

The current part aims at providing a sketch on the current global situation concerning the socioeconomic inequalities and the problematization of the unequal enjoyment of the socioeconomic opportunities. In this regard, the wide socioeconomic inequalities are connected with the underfulfillment of socioeconomic rights and to some extent with their current theoretical conceptualization. Nevertheless, it is important to clarify that the justification of the universal status of socioeconomic rights, along with the recognition of the protection of these rights as a matter of global justice, can nowise be proved by the global rise in socioeconomic inequalities. However, it may be true that one of the factors which lead to the widening of global socioeconomic inequalities is the current underassessment of the status of socioeconomic rights. That is the reason why, the debate of global socioeconomic inequalities and injustices cannot ignore the concept of socioeconomic rights, which, to some extent, can be considered the link between the empirical research on socioeconomic inequalities and their critical problematization in the fields of political philosophy and normative theories on socioeconomic injustice.

\section{The contemporary global socioeconomic inequalities}

The sharp growth in socioeconomic inequalities at the global level can be considered one of the most relevant challenges of our era. Indeed, inequalities at the local level are relatively small comparing to inequalities at the global level - a shred of evidence which does not surprise but which is widely neglected and/or underestimated. As a matter of fact, this focal issue is one of the main causes of other global endemic problems such as sharply unequal standards of living, massive migrations, global discrimination in opportunities, environmental degradation (Singer, 2004; Caney, 2005; Dodds, 2005; Omoniyi, Gupta, 2007; Brown, 2009). The growth in socioeconomic inequalities underlies a lack of protection, along with an inapt comprehensive theoretical understanding, of socioeconomic rights at the global level whose problematization seems not to capture the proper attention it deserves.

Hence, individuals may suffer morally arbitrary discrimination in the enjoyment of rights, with negative effects on their lives which are by now clear to everyone. Indeed, the seventeenth century Kantian argumentation and foresight that «the intercourse, more or less close, which has been everywhere steadily increasing between the nations of the earth, has now extended so enormously that a violation of right in one part of the world is felt all over it» (Kant, 1903: 142) is for sure more true now than ever before. Indeed, thanks to the current global interconnectedness and interdependence - which in Pogge (2008) are also relevant for the distribution of the responsibility for the global socioeconomic inequalities - the acknowledgement of the current level of global socioeconomic inequalities, along with the related unequal secure access to the object of the socioeconomic rights, cannot be denied anymore and deserve proper investigation.

Even though there are disagreements on the empirical measurement and evaluation of socioeconomic inequalities, the scholars dealing with this topic broadly agree to denote a growth of phenomena of socioeconomic inequalities, occurred in different dimensions in the last two decades, at the national level and, even more, at the global one (Jomo, 2007; Lenger, Schumacher, 2015). Just to provide an overall but explicative picture of the severity of the growth of wealth inequalities in the recent years, the Oxfam report on wealth inequalities published in 2018 points out that eighty-two percent of the wealth generated in the year 2017 went to the richest one percent of the global population, while the 3.7 billion people who make up the poorest half of the world saw no increase in their wealth (Oxfam International, 2018: 2). Moreover, the same report, retrieving the evidence coming from the Credit Suisse Research Institute's Global Wealth Report 
(2018: 10), reveals that, in 2017, 42 people owned the same wealth of the half poorest of humanity, while, in 2016, the number of people was 61. About the historical evolution of socioeconomic inequalities, even though, between 1990 and 2010, the number of people living in extreme poverty (i.e. on less than $\$ 1.90$ a day) halved, and has continued to decline since then (Hardoon, 2015), the World Inequality Report (2018) from the World Inequality Lab shows that the top 1\% captured $27 \%$ of total global income growth between 1980 and 2016. Meanwhile, the bottom 50\% only received half of that, i.e. $12 \%$ of total income growth, marking a steady trend in the unequal distribution of the global income wealth. A plan to end severe poverty for over 2.5 billion human beings - whose aggregate shortfall amounts to barely $\$ 300$ billion annually which are well under the 1 percent of the aggregate annual gross national product of the high-income economies could be carried out through reforms which would entail a negligible reduction in the standard of living for the 1 billion people living in the high-income countries (Pogge, 2008: 10).

The structural margin of error affecting these data, above all related to different criteria of measurement and evaluation, cannot be a valid justification of the current level of socioeconomic inequalities whose persistence ought to be considered shameful and, to some extent morally untenable, according to the always more powerful technological means available to tackle it, the growing awareness of this crucial issue and the supposed great progress in moral norms (Pogge, 2008: 5).

Moreover, global, supranational, transnational, international inequalities are much wider, and, for this, more worrying, than those at the national state level but they catch much less attention (Beck, 2005). As a matter of fact, the theoretical studies and empirical research dealing with global socioeconomic inequalities are relatively marginal comparing to those related to national inequalities. The attitude to focus on regional issues, such as, in this case, the national socioeconomic inequalities, has long affected not only the social sciences, including the above-mentioned noteworthy works of Piketty and Stiglitz (Giovanola, 2016: 61) but also, more or less consciously and directly, few moral and political cum philosophical sixteenth-through twentieth-century theories of which the 'particularistic universalism' of authors from the modern era, such as De Vitoria (Tedesco, 2009), is an example. This methodological nationalism (Beck, 1999), or regionalism, lacks to take into account the special and temporal revolution of the global era adopting a local view rather than a global perspective. This fact can also explain the perceived marginality of the huge global inequalities comparing to the attention captured by the national inequalities. This phenomenon can be also seen as a consequence of the relative «mutual isolation and lack vivid awareness of one another's circumstances, experiences, and perspectives on the world» (Pogge, 2008: 4). As a matter of fact, in different spheres of human life, wealth societies are slightly concerned about global inequalities because they live in extreme isolation from severe poverty. As stressed out by Pogge (2008: 4) «the one-third of human beings who die from poverty-related causes includes no one we have ever spent time with. [...]. If we had such people as friends or neighbours, we would think harder to help end this ongoing catastrophe». Thus, we may suppose that if the poorest of the world starving to death were neighbour of the affluent countries' inhabitants, the latter would probably care more about this focal issue affecting humanity. Thus, global inequalities are broadly unable to catch the proper attention they would deserve not only because politics and, relatively less academia, do not focus on them but also because they are not commonly perceived as a matter of concern, which are two factors, in any case, strongly intertwined.

\section{The normativity bias of the methodological nationalism}

The methodological nationalism, and its related normative nationalism, take the nation-state and its borders as the unit of analysis (Sassen, 2007) and/or as the limit of the validity of the theoretical elaborations on socioeconomic inequalities. This fact may also affect those theories which presume to address the human being as such, taking them as the main unit of reference, and seek to outline universally valid principles. As a consequence, the claim of universality of some philosophical theories loses appeal insofar as they lack in being detached, or at least detachable, from the local context and, above all, in making their tenets valid for the whole world. Thus, this alleged bias is relevant insofar as it may jeopardize the universal claim of the philosophical and political reflection. For example, John Rawls (1971, 1985, 1993), which had the merit to foster the debate on social justice, cannot be considered immune to criticisms of this sort insofar as his reasoning shows to be conditioned by this rooted model of thought. Indeed, in his essay The Law of Peoples the principles of international justice are based on the category of people understood as «State unity, territoriality, morality and memory» (Giovanola, 2016: 66) and they differ from the principles of justice singled out in its main work $A$ Theory of Justice. In his theory of justice, described also in the essay Justice as fairness, the second principle of justice refers to socioeconomic inequalities, basically arguing that they are acceptable as 
long as they are in favour of the worst-off, however, along with the first principle, in the framework of his overall reasoning, they end up to be valid only within the borders of the national society.

The same critique affects the Rawlsian account of the lottery of birth, a philosophical argument used also by the social contract theorists Thomas Hobbes, John Locke, and Jean-Jacques Rousseau (Martinez, 2016) and which may be one of the strongest points against socioeconomic inequalities to be assessed as morally arbitrary. Indeed, the lottery of birth, as the term itself may suggest, points out the fact that since human beings do not decide where to be born, no one ought to be held responsible for the available opportunities linked to the place of birth and natural assets. According to Rawls, «distributive shares are decided by the outcome of the natural lottery; and this outcome is arbitrary from a moral perspective. There is no more reason to permit the distribution of income and wealth to be settled by the distribution of natural assets than by historical and social fortune. [...]. Therefore, we may want to adopt a principle which [...] mitigates the arbitrary effects of the natural lottery itself» (Rawls, 1971: 64). Thus, a human being with special needs as well as a person born in a really poor place or family cannot be considered responsible for their lack of opportunities comparing to the others and, accordingly, the unequal distribution of socioeconomic opportunities, deriving from morally arbitrary factors, ought to be subject to some kind of redistribution. According to Rawls, undeserved inequalities call for redress; and since inequalities of birth and natural endowment are undeserved, these inequalities are to be somehow compensated for. Thus, the principle holds that in order to treat all persons equally, to provide genuine equality of opportunity, society must give more attention to those with fewer native assets and to those born into the less favorable social positions. The idea is to redress the bias of contingencies in the direction of equality (Rawls, 1971: 86).

Since the principle of redress excludes the better off and would claim for excessive compensation which may lead to other downsides, Rawls opts for another redistributive principle, the different principle, which, however, does not discard the idea of redressing undeserved inequalities related to natural assets and social condition. Therefore, the concept of the lottery of birth underlines the unjustifiable fortuity, along with the moral arbitrariness, of the allocation of socioeconomic opportunities related to social circumstances and natural assets, which would give persons a right to have some kind of compensation. Still, even though socioeconomic inequalities related to social circumstances are wider and more worrying at the global level Rawlsian international principles of social justice are much less demanding than those applying at the local level, showing that moral standards lose their validity beyond the national borders.

\section{The universal socioeconomic (in)justices}

«Injustice, then, is simply inequalities that are not to the benefit of all» John Rawls

The term universal justice (Pogge, 2008: 33) may be understood as an empty tautology insofar as justice, as a moral concept should be, at least theoretically, universal by its very own nature. Indeed, conceiving morality in normative terms means «to refer to a code of conduct that, given specific conditions, would be put forward by all rational persons» (Gert, 2020). However, this universal characterization of justice aims at underlining the attempt to conceive justice in such a way that its conceptualization refers to the global human society as a whole and, thus, does not infringes in the borders of the national state.

Thus, before delving into the criterion according to which it is possible to assess the injustice of global socioeconomic inequalities a brief description of the moral conception of justice is carried out. However, the aim of the current part is not an in-depth and exhaustive discussion of the concept of justice which would be improperly ambitious and would go beyond the purpose of this article. Rather, the moral conception of justice will only be addressed in its universal meaning through the analysis of those elements of justice which are useful to assess the injustice of global socioeconomic inequalities.

The previous part highlights the grim of socioeconomic inequalities at the global level, which is an undeniably gruesome and untenable fact. Even one of the most sceptical authors toward global justice, Thomas Nagel, admits that «whatever view one takes of the applicability or inapplicability of standards of justice to such a situation, it is clearly a disaster from a more broadly humanitarian point of view» (Nagel, 2005). However, though the global socioeconomic inequalities are a humanitarian emergency, - which, for some authors (Pogge, 2008: 15), mainly cosmopolitans, is itself, strictu sensu, a reason of injustice, while for others (Nagel, 2005: 117; Rawls, 2001), mainly statists, it is not - the point is to understand to what extent these inequalities are issues related to justice. Therefore, as previously anticipated, the following reasoning seeks to provide an answer to the questions: What are the socioeconomic inequalities definable as unjust (under- 
stood as unfair)? And, what are the reasons according to which the correction of those unjust (or unfair) inequalities ought to be softened?

Even though contemporary philosophers, above all egalitarian ones, widely disagree on what is the currency to be equally distributed (Sen, 1980; Cohen, 1989; 1990; Norman, 1990) there is a broad consensus on the fact that the current global distribution is to some extent unjust (Heinze, 2012). Thus, regardless the specific basic good - broadly and abstractly conceived - to take into account as the currency of basic justice, such as Rawls' social primary good (1971: 53), Dworkin's resources (1988: 311), capabilities for Sen (1980) and Nussbaum (2011), Arneson's welfare (1989), Nozick's liberty-rights (1974), there are some criteria (which, of course, differ among authors) leading to consider the socioeconomic inequalities as unjust or unfair.

Recalling the philosophical argument of the lottery of birth, this analysis focuses on arbitrariness, of natural contingencies and social fortune, and on personal responsibility as the main elements to assess the unjust socioeconomic inequalities. At first glance, socioeconomic injustices may be conceived as those socioeconomic inequalities which are morally arbitrary i.e. which are independent from the agent's responsibility. According to this assumption, persons who are worse off because of natural contingencies, such as less favoured in terms of merit, or social fortune, such as being born in a place of the world or a specific family rather than another, would have the right to claim for some kind of compensation for burdens related to undeserved inequalities of natural endowment and/or birth.

The full redress of undeserved, and, in this understanding, unjust, inequalities and the consequent justifiable claim to full compensation is not completely tenable and applicable since, as underlined by Rawls, it has to be balanced with other principles and has to take into account practical issues of feasibility.

Three Rawlsian objections are taken into account in order to understand why this claim to full compensation must be resized. Firstly, the implementation of the principle of redress is limited by the factual impossibility to compensate some natural and morally arbitrary inequalities such as «evening out handicaps as if all were expected to compete on a fair basis in the same race» (Rawls, 1971: 86). Thus, the right to compensation must be restricted according to the material and practical feasibility of its implementation. However, taking into account only socioeconomic inequalities, the Rawlsian objection to the redress of natural inequalities would be partially overruled since the compensation is called for here regards only undeserved socioeconomic inequalities (which may be, in any case, to some extent the effects of natural inequalities and would not be considered completely unjust if they are related to the personal responsibility).

Secondly, conceiving injustice as «simply inequalities that are not to the benefit of all» (Rawls, 1971: 53) the full redress of socioeconomic inequalities would result in a zero-sum game which would only entail liberty-rights violation. Indeed, in a full compensation scheme not the benefit of all are taken into account but only that of people who are relatively worse off. In this understanding, undeserved inequalities can be redressed insofar as do not unreasonably harm the benefits of people who are better off. To defend the principle of redress of socioeconomic inequalities against this second objection two answers can be provided. The first, which may be considered to recall to some extent the theory of prioritarianism, is that the claims of the worst-off are more relevant than those of people who are better off insofar as burdens faced by the worstoff are much more important, as basic, for a worthwhile life than those of people who are better off. This assumption seems difficult to be confuted, at least in principle, above all thinking about a comparison of the preferences of these two categories. Even though it may be intuitive to accept the fact that adequate standards of living would be a basic element for a worthwhile life an example may clarify this point. Indeed, an adequate standard of living may mean a piece of bread for a person suffering severe poverty while may consist in enjoy oysters for a billionaire. However, looking at the very basic need in question, the hunger, these two persons are satisfying to have an adequate standard of living, there is no difference in the functioning of these two goods which, thus, underlines a priority of the basic need over the specific value of the good. Accordingly, even supposing that the billionaire claims that he can only appease his hunger with oysters thus accomplishing his conception of adequate standard of living, if he will go bankrupt he would probably accept something much less expensive than the oysters to feed him/herself. That is to say that there are needs, correlated to specific benefits, which have priority toward others insofar as the impossibility to satisfy a basic need, as feeding hunger, ought to be admitted to be much worse than the impossibility to satisfy a secondary need, as enjoying oysters. A second answer, which follows from the previous one, is a resizing of the redress of socioeconomic inequalities the extent to which basic socioeconomic opportunities are ensured. The latter ought to be theoretically and effectively recognized to each human being since even those persons, which, in principle, ought to shoulder the compensation for undeserved socioeconomic inequalities, can accept a partial application of the principle of redress in order to universally recognized secure access to the basic socio- 
economic opportunities which they would never deny for themselves. Moreover, the duties to redress socioeconomic inequalities imposed on others would be justified by the fact that the socioeconomic opportunities, related to natural asset and social condition, the well-off can exploit are undeserved, and, thus, they have an obligation to compensation.

Lastly, another objection against the principle of redress is that the general claim for compensation ought to be assessed also in relation to the direct responsibilities of others for the unjust distribution of socioeconomic opportunities. That is to say that individuals have the right to call for compensation in the case in which the burden has been directly caused by other persons (which can be considered responsible for that harm). As a matter of fact, it would make no sense, from a practical point of view, to recognize to Amerindians suffering thirsty and fame a right to compensation toward Europeans in the first millennium. Rather different is the reasoning for the current era where some responsibilities of the persons and peoples which are better off for the burden of persons and peoples who are worse off may be conceived and the unjust distribution of socioeconomic opportunities may be linked to a specific global institutional order (Pogge, 2008: 52). However, the second requirement for compensation does not discard the validity of the first one (as long as this is not disproved even against the 'feasibility proof' sketched out in the above-mentioned example). Rather, it can strengthen the justifiability of the claim to redress global socioeconomic inequalities. To sum up, the arbitrariness of distribution of socioeconomic opportunities and responsibilities for the lack of the correction of this unfair distribution can be considered two reasonable elements to demonstrate the validity of the principle of redress and, accordingly, assess the injustice of socioeconomic inequalities.

$$
* * *
$$

The article has tried to demonstrate that the widespread focus on national socioeconomic inequality, so-called methodological nationalism, is not only a problem of empirical research but affects also social and philosophical reflections, turning into a normative nationalism. Indeed, even a preeminent scholar, like John Rawls, which has revived the debate on social (in)justice is not immune from a normativity bias deriving from the rooted methodological nationalism.

The arguments of the lottery of birth and the related principle of redress of morally arbitrary inequalities provide a valid and appealing understanding of the extent to which socioeconomic inequalities ought to be considered as unjust. Accordingly, socioeconomic inequalities ought to be assessed as unjust, thus be redressed, the extent to which they are undeserved, since morally arbitrary, such as those related to the natural lottery. Indeed, the latter makes the distribution of socioeconomic opportunities arbitrary, thus unjust, insofar as this distribution is determined by natural assets and historical and social fortune.

However, this article discusses only one aspect of the unfairness of inequalities since the compensation of socioeconomic inequalities must be balanced with the protection of individual liberties. Accordingly, further research can be directed to the crucial relation between different kinds of inequality, such as liberties and socioeconomic opportunities or conditions, as well as effective and efficient measures to fight against inequalities of socioeconomic opportunities and basic liberties at the global level.

What is sure is that the contemporary global inequality is a gruesome fact, deeply related to other crucial global challenges, such as economic migration and environmental degradation, with which humankind must deal always more. To this aim, empirical research and normative theories cannot anymore address socioeconomic inequalities and injustices only as a national matter but they must give proper relevance also to the global level.

\section{References}

Arneson, R. (1989) 'Equality and Equal Opportunity for Welfare', Philosophical Studies, 56(1), pp. 77-93.

Atkinson, A. (2015) Inequality: what can be done?. Cambridge: Harvard University Press.

Bauman, Z. (2011) Collateral Damage: social inequalities in a global age. Cambridge: Polity Press.
Beck, U. (1999) What is globalization? Translated by P. Camiller. Cambridge: Polity Press.

Beck, U. (2005) Cosmopolitan vision. Translated by C. Cronin. Cambridge: Polity Press.

Brown, L. (2009) Plan B 4.0, Mobilizing to save civilization. New York: W.W. Norton \& Company.

Caney, S. (2005) 'Cosmopolitan Justice, Responsibility, and Global Climate Change', Lei- 
den Journal of International Law, 18(4), pp. 747-775.

Cohen, G. (1989) 'On the currency of Egalitarian Justice', Ethics, 99(4), pp. 906-944.

Cohen, G. (1990) 'Equality of What, On welfare, Goods and Capabilities', Recherches Économiques de Louvain / Louvain Economic Review, 56(3/4), pp. 357-382.

Dodds, K. (2005) Global Geopolitics: A Critical Introduction. Edinburgh: Pearson Education.

Dworkin, R. (1977) Taking rights seriously. Cambridge: Harvard University Press.

Dworkin, R. (1981) 'What is Equality? Part 2: Equality of Resources', Philosophy and Public Affairs, 10(4), pp. 283-345.

Dworkin, R. (2002) Sovereign Virtue: The theory and practice of Equality. Cambridge: Harvard University Press.

Ferrajoli, L. (2001) Diritti fondamentali. Un dibattito teorico. Roma-Bari: Laterza (In Italian).

Ferrajoli, L. (2013) La democrazia attraverso $i$ diritti. Roma-Bari: Laterza. (In Italian).

Gallino, L. (2009) Globalizzazione e disuguaglianze. 4th ed. Roma-Bari: Laterza (In Italian).

Gert, B., Gert, J. (2020) 'The definition of morality' in Zalta, E.N. (ed.), The Stanford Encyclopedia of Philosophy. Metaphysics Research Lab. Available at: URL: https://plato.stanford.edu/cgi-

bin/encyclopedia/archinfo.cgi?entry=mora lity-definition (Accessed: 20 November 2020).

Giovanola, B. (ed.) (2016) Etica pubblica, giustizia sociale, diseguaglianze. Roma: Carocci (In Italian).

Hardoon, D., Slater, J. (2015) Inequality and the end of extreme poverty. London: Oxfam GB.

Held, D. (2007) Global Inequality. Patterns and Explanations. Cambridge: Polity Press.

Heinze, E. (2012) The concept of injustice. London: Routledge.

Jomo, K.S., Baudot, J. (eds.) (2007) Flat World, Big Gaps. London: Zed Books.

Kant, I. (1795) Perpetual peace: A philosophical Sketch. Edited and translated by M.C. Smith (1903) London: George Allen \& Unwin Brothers.

Lenger, A., Schumacher, F. (eds.) (2015) Understanding the Dynamics of Global Inequality. Social Exclusion, Power Shift and Structural Changes. Heidelberg-New York: Springer.
Martinez, R. (2016) Creating Freedom, power, control and the fight for our future. Edinburgh: Canongate books.

Milanovic, B. (2016) Global Inequality: A New Approach for the Age of Globalization. Cambridge: Harvard University Press.

Nagel T. (2005) 'The problem of Global Justice', Philosophy \& Public Affairs, 33 (2), pp. 113-147.

Norman, D. (1990) 'Equality of What: Welfare, Resources, or Capabilities?', Philosophy and Phenomenological Research, 50, pp. 273-306.

Nozick, R. (1974) Anarchy, State, and Utopia. New York: Basic Books.

Nussbaum, M. C. (2011) Creating Possibilities. Cambridge: Harvard University Press.

Omoniyi, T., Gupta, S. (2007) The Cultures of Economic Migrations, International Perspectives. Ashgate Publishing.

Oxfam international (2018). Reward work, not wealth. London: Oxfam GB.

Piketty, T. (2013) Capital in the twenty-first century. Translated by A. Goldhammer. Cambridge: Harvard University Press.

Pogge, T. (2008) World Poverty and Human Rights, Cosmopolitan Responsibilities and Reforms. 2nd edn. Cambridge: Polity press.

Rawls, J. (1971) A Theory of Justice. Cambridge: Harvard University Press.

Rawls, J. (1985) 'Justice as Fairness: political not metaphysical', Philosophy and Public Affairs, 14 (3), pp. 223-251.

Rawls, J. (1993) Political liberalism. New York: Columbia University Press.

Rawls, J. (1999) The Law of People. Cambridge: Harvard University Press.

Sassen, S. (2007) A sociology of Globalization. New York: W.W. Norton \& Company.

Sen, A. (1980) 'Equality of What' in McMurrin, S.M. (ed.) Tanner Lectures on Human Values, Volume 1. Cambridge: Cambridge University Press.

Sen, A. (1992) Inequality Reexamined. Cambridge: Harvard University Press.

Sen, A. (2009) The idea of justice. Cambridge: Harvard University Press.

Singer, P. (2004) One World, The ethics of globalization. New Haven: Yale University Press.

Stiglitz, J. (2012) The price of Inequality. New York: W. W. Norton \& Company.

Tedesco, F. (2009) Diritti umani e relativismo. Roma-Bari: Laterza. 
Therborn, G. (2013) The Killing Fields of Inequality. Cambridge: Polity press.

Статья поступила в редакцию: 27.11.2020

Статья принята к печати: 30.01.2021
Urbinati, N. (2017) 'La (impossibile) giustificazione delle disuguaglianze', Questione giustizia, 2, pp. 41-45.

\title{
О (НЕ)СПРАВЕДЛИВОСТИ ГЛОБАЛЬНОГО СОЦИАЛЬНО-ЭКОНОМИЧЕСКОГО HEPABEHCTBA
}

\section{Фабио Коаччи}

Коаччи Фабио, аспирант, преподаватель кафедры мировых политических процессов, Факультет управления и политики, МГИМО МИД России, Москва.

Ассистент преподавателя кафедры политологии, коммуникации и международных отношений, Университет Мачераты, Италия.

E-mail: f.coacci1@unimc.it. (ORCID: 0000-0002-4504-6067).

\begin{abstract}
Аннотация
Глобальное социально-экономическое неравенство - одна из величайших проблем современной эпохи. В данной статье делается попытка представить картину текущего социально-экономического неравенства на глобальном уровне и проанализировать, в какой степени его следует оценивать как несправедливое. Для достижения этой цели исследуются эмпирические данные, связанные с ростом глобального социально-экономического неравенства, и критически оценивается их значение в свете принципа устранения морально произвольного неравенства. В статье утверждается, что на глобальное социально-экономическое неравенство влияют две актуальные проблемы как с методологической, так и с нормативной точек зрения. Эмпирический анализ показывает, что существует широко распространенный методологический национализм, который ставит под угрозу обсуждение социально-экономического неравенства на глобальном уровне, в то время как критическая оценка социальноэкономического неравенства показывает, что его несправедливость можно защитить даже от возражений Роулза против принципа возмещения ущерба морально произвольных неравенств.
\end{abstract}

Ключевые слова: социально-экономическое неравенство; глобализация; произвол; несправедливость; методологический национализм. 